\title{
SINERGITAS PEMERINTAH DESA DAN KELEMBAGAAN LOKAL SUBAK DALAM MEWUJUDKAN PEMBANGUNAN BERKELANJUTAN BERBASIS SUBAK SEBAGAI WARISAN BUDAYA DUNIA ( STUDI KASUS : SUBAK JATILUWIH, KABUPATEN TABANAN)
}

\author{
SINERGITY OF VILLAGE GOVERNMENT AND LOCAL SUBAK \\ INSTITUTION IN REALIZING SUSTAINABLE DEVELOPMENT BASED \\ ON SUBAK AS A WORLD CULTURAL HERITAGE \\ (CASE STUDY : SUBAK JATILUWIH, TABANAN REGENCY)
}

\author{
Komang Trisna Febriantini, Ni Kadek Indriani, Bima Oktadinata Kusuma, Ni \\ Komang Yuli Yuniari \\ Program Studi Ilmu Administrasi Negara Fakultas Ilmu Sosial dan Ilmu Politik \\ Universitas Udayana \\ komangtrisna621@gmail.com
}

\begin{abstract}
Abstrak
Penelitian ini bertujuan untuk mengetahui sinergitas pemerintah desa dengan kelembagaan lokal subak dalam mewujudkan pembangunan berkelanjutan di daerah pedesaan berbasis Subak sebagai warisan budaya dunia (WBD) dimana WBD merupakan terobosan wisata alternatif yang akan dapat mensinergikan potensi Desa Jatiluwih berdasarkan budaya, mempertahankan keberadaan potensi tempat wisata dan meningkatkan ekonomi masyarakat sekitar berdasarkan peran sinergi dari pemerintah desa dan lembaga subak yang ada. Penelitian ini ingin mengetahui sinergi pemerintah desa dan lembaga subak lokal dalam mewujudkan pembangunan berkelanjutan ditinjau dari segi komunikasi dan koordinasi menurut Najiyati (2011) dan dianalisis menggunakan metode deskriptif kualitatif yang menghasilkan data deskriptif yang diperoleh melalui penelitian kepustakaan, observasi, dokumentasi, dan wawancara mendalam dengan informan. Hasil dari penelitian ini diharapkan dapat menjelaskan proses koordinasi dan komunikasi antara Pemerintah Desa Jatiluwih dan kelembagaan lokal subak dalam pembangunan desa termasuk kendala yang dialami dalam proses komunikasi dan koordinasi.
\end{abstract}

Kata Kunci : Sinergitas, pemerintahan desa , subak, warisan budaya dunia

\begin{abstract}
This research about synergy of village government with local subak institutions in realizing sustainable development in Subak-based rural areas as a world cultural heritage (WBD) is an alternative tourism breakthrough that will be able to synergize the potential of Jatiluwih Village based on culture, maintaining the existence of potential tourist attractions and improving the economy of the surrounding community based on the role of the synergy of the local government
\end{abstract}


and the existing subak institutions. This study wanted to find out the synergy of indigenous village government and subak local institution in realizing Subakbased rural development as a World Cultural Heritage, which was reviewed in terms of communication and coordination according to Najiyati et al (2011) and analyzed using qualitative descriptive methods that produced descriptive data obtained through library research, observation, documentation, and in-depth interviews with informants. The results of this study are expected to be able to explain the process of coordination and communication between the Jatiluwih Indigeneous Government and the local subak institutions that are in the development of the village including the obstacles experienced in the communication and coordination process.

Keywords: sinergity, village government, subak, world cultural heritage

\section{A. Pendahuluan}

Pemahaman mengenai desa berdasarkan Undang-Undang No. 6 Tahun 2014 merupakan tonggak perubahan paradigma pengaturan desa dimana desa tidak hanya dianggap sebagai objek pembangunan melainkan telah ditempatkan menjadi suatu subjek dan ujung tombak dari pada pembangunan dan peningkatan kesejahteraan masyarakat. Hal ini sesuai dengan jargon dari pemerintahan Presiden Jokowi yakni membangun Indonesia dari daerahdaerah pinggiran. Dengan adanya usaha memperkuat daerah pinggiran dalam kerangka Negara Kesatuan Indonesia maka secara langsung akan berpengaruh terhadap kemajuan suatu Negara.

Desa telah diberikan kewenangan oleh pemerintah pusat untuk mengatur dan mengurus urusan pemerintahan, kepentingan masyarakat setempat berdasarkan prakarsa masyarakat, adat istiadat, dan nilai sosial budaya yang dimiliki oleh desa itu sendiri. Salah satu contohnya adalah pemerintahan desa adat yang ada di Bali. Adapun Desa Adat berdasarkan Peraturan Daerah Provinsi Bali Nomor 4 Tahun 2019 didefinisikan sebagai desa yang tumbuh dan berkembang selama berabad-abad serta memiliki hak asal usul, hak tradisional, dan hak otonomi asli untuk mengatur rumah tangganya sendiri. Adapun sistem penyelengaraan pemerintahan yang khas berdasarkan adat istiadat dan budaya dari daerahnya seperti pemerintahan desa adat di Bali tersebut saat ini kita kenal dengan istilah Local Indigeneous Governance. Local Indigeneous Governance merupakan suatu sistem pemerintahan yang berbasis pemerintahan adat beradasarkan kearifan lokal yang dimiliki oleh satu daerah.

Salah satu contoh penerapan Local Indigeneous Governance tersebut adalah desa adat yang ada di Provinsi Bali, dimana kekayaan adat istiadat dan keteguhan masyarakat 
Bali dalam mempertahankan adat isitiadat dan tradisi telah mampu menghasilkan sebuah sistem pemerintahan baru yang tercermin pada administrasi pemerintah di Bali dimana adanya dualisme pemerintahan dalam satu lingkup wilayah pedesaan berupa Desa Dinas dan Desa Adat. Selain itu, besarnya pengaruh yang diberikan Pemerintahan Desa Adat di Bali dalam mendukung pembangunan termasuk salah satunya pembangunan pariwisata telah menunjukan seberapa besar eksistensi Desa Adat di Bali yang sampai saat ini tetap terjaga bahkan bisa melampaui peran pemerintah desa dinas dalam pengaruhnya kepada masyarkat. Hal inilah yang membuat masyarakat desa di Bali sangat terikat dengan adat serta semua kelembagaan yang terikat langsung dengan adat. Salah satu lembaga yang dimaksud dan berada dibawah naungan adat tersebut adalah Kelembagaan Lokal Subak.

Setelah ditetapkannya salah satu Subak di Bali sebagai warisan budaya dunia oleh UNESCO pada tahun 2012 perhatian public di Bali dan Indonesia tertuju pada kawasan persawahan luas di Desa Jatiluwih. Desa Jatiluwih merupakan salah satu desa yang terletak di Kabupaten Tabanan dimana Kabupaten Tabanan secara luas dianggap sebagai rice barn atau lumbung Bali. Hal ini juga dibuktikan dengan ditetapkannya kawasan Jatiluwih menjadi World Culture Heritage selain itu juga telah berpengaruh terhadap kunjungan wisatawan ke Jatiluwih setiap tahunnya. Dengan adanya peningkatan kunjungan wisatawan tersebut memicu pemerintah dan masyarakat untuk menstabilkan dan meningkatkan kualitas pariwisata melalui strategi pengembangan desa wisata. Tetapi dengan adanya pengembangan desa wisata yang bertujuan untuk memperkenalkan kepada pengunjung tentang keindahan alam Desa Jatiluwih dan kehidupan masyarakat lokalnya telah memberikan pengaruh terhadap peningkatan jumlah kunjungan wisatawan yang akan berimplikasi terhadap peningkatan fasilitas pariwisata yang diperlukan. Kondisi ini mengakibatkan terjadinya pertumbuhan pembangunan fasilitas penunjang pariwisata seperti rumah makan dan home stay yang tidak terkendali serta bertentangan dengan aturan tata ruang yaitu Perda Kabupaten Tabanan No. 6 Tahun 2014 tentang Kawasan Jalur Hijau.

Maka, untuk mengatasi berbagai permasalahan tersebut diperlukan sinergitas antara seluruh stakeholder terkait melalui proses sinergitas. Menurut Najiyati dan Rahmat (2011) sinergitas dimaksudkan sebagai operasi gabungan atau perpaduan unsur untuk menghasilkan output yang lebih baik. Sinergitas berarti suatu kesatuan yang utuh, kuat antara elemen satu dengan yang lainnya yang saling memperkuat dan tidak dapat dipisahkan. Sinergitas dapat 
terbangun melalui dua cara yaitu komunikasi dan koordinasi. Komunikasi dibedakan menjadi 2 bagian yaitu sebagai suatu kegiatan untuk memindahkan stimulus guna mendapat tanggapan dan yang berorientasi pada kegiatan dimana seseorang menerima stimuli rangsangan. Sedangkan Koordinasi berguna untuk menciptakan sinergitas yang baik demi mendukung kelancaran komunikasi.

Moekijat (1994) menyebutkan ada 9 syarat untuk mewujudkan koordinasi yang efektif, yaitu :

1. Hubungan Langsung

2. Kesempatan awal

3. Kontinuitas

4. Dinamisme

5. Tujuan yang jelas

6. Organisasi yang sederhana

7. Perumusan wewenang dan tanggung jawab yang jelas

8. Komunikasi yang efektif

9. Kepemimpinan supervise yang efektif

Melalui pengertian sinergitas diatas, dapat disimpulkan bahwa sinergitas adalah kegiatan gabungan atau kerjasama yang dilakukan guna mendapatkan hasil yang lebih maksimal dengan tetap menjaga komunikasi dan koordinasi

Dalam mengatasi berbagai permasalahan yang terjadi tentunya keterlibatan masyarakat desa, pemerintahan desa yakni Desa Adat dan Desa Dinas maupun Kelembagaan Lokal Subak serta dukungan pemerintah daerah khususnya Dinas Pariwisata Kabupaten Tabanan sangat di perlukan Sehingga dalam pengembangan pembangunan di Desa Jatiluwih seluruh pihak harus berperan secara keseluruhan mulai dari tahap perencanaan, pengawasan, dan implementasi. Apabila seluruh pihak telah bersinergi, khususnya pemerintah desa adat dan kelembagaan lokal subak tentunya akan dapat mencapai tujuan akhir dalam pembangunan di Desa Jatiluwih. Berangkat dari pemaparan latar belakang tersebut maka penulis tertarik untuk mengangkat judul penelitian :"Sinergitas Pemerintah Desa dan Kelembagaan Lokal Subak dalam Mewujudkan Pembangunan Berkelanjutan di Pedesaan berbasis Subak Sebagai Warisan Budaya Dunia (Studi Kasus : Subak Jatiluwih, Kabupaten Tabanan)". Berdasarkan latar belakang diatas dapat ditarik rumusan masalah yakni bagaimana sinergitas Pemerintah Desa dan Kelembagaan Lokal Subak dalam mewujudkan pembangunan berkelanjutan di pedesaan berbasis Subak sebagai Warisan Budaya Dunia (Studi Kasus : Subak Jatiluwih, Kabupaten Tabanan).

\section{B. Metodelogi Penelitian}

Penelitian ini merupakan penelitian deskriptif kualitatif. Menurut Danzin dan Linclon Satori (2014) penelitian kualitatif merupakan penelitian yang menggunakan latar alamiah, dengan maksud menafsirkan fenomena yang terjadi dan dilakukan dengan jalan 
melibatkan berbagai metode yang ada. Penelitian ini mengambil lokasi di Dinas Pariwisata Kabupaten Tabanan dan Desa Jatiluwih, Kecamatan Penebel, Tabanan dimana objek penelitian pada penelitian ini, yaitu Dinas Pariwisata Kabupaten Tabanan, Pemerintahan Desa dan Kelembagaan Lokal Subak yang bersinergi dalam pembangunan berkelanjutan berbasis subak sebagai Warisan Budaya Dunia di Desa Jatiluwih, Kabupaten Tabanan.

Adapun teknik analisis data kualitatif yang digunakan dalam penelitian kualitatif adalah analisis data dilakukan secara bersamaan, yaitu reduksi data, penyajian data, penarikan kesimpulan atau verifikasi. Pada penelitian ini penulis menggunakan teknik pengumpulan data yaitu, wawancara, observasi dan dokumentasi

\section{Hasil dan Pembahasan}

Sebagai daerah yang memiliki lahan pertanian subur dengan mayoritas masyarakat yang hampir keseluruhan berprofesi sebagai petani, Desa Jatiluwih memiliki suatu kelembagaan lokal yang disebut dengan subak yang beranggotakan para petani dimana pada tahun 2012 UNESCO telah menetapan Subak di Desa Jatiluwih sebagai Warisan Budaya Dunia (WBD). Namun pemberian predikat sebagai Warisan Budaya Dunia tersebut telah memberikan dampak positif dan negatif bagi Desa Jatiluwih dimana dengan predikat
WBD tersebut jumlah kunjungan wisatawan akan semakin meningkat. Hal tersebut akan berdampak langsung terhadap peningkatan jumlah fasilitas penunjang pariwisata yang dikhawatiran dapat menggerus lahan pertanian di Desa Jatiluwih walaupun pembangunan tersebut dilakukan diluar daerah sawah abadi (jalur hijau).

Pada dasarnya kegiatan pertanian di Desa Jatiluwih memang bersinergi dengan parwisata yang ada. Tetapi, dengan adanya perkembangan pariwisata yang pesat tersebut tentu saja akan menghadirkan beberapa hal yang nantinya dapat menjadi ancaman bagi Desa Jatiluwih karena semakin lama perkembangan tersebut secara langsung berpengaruh terhadap pesatnya pembangunanpembangunan fasilitas penunjang pariwisata yang nantinya tidak sesuai dengan prinsip pembangunan berkelanjutan. Maka dari itu, dengan adanya pemberian predikat subak sebagai warisan budaya dunia oleh UNESCO ini pelindung bagi eksistensi Subak Jatiluwih dari arus alih fungsi lahan disamping adanya keberadaan undang-undang tentang kawasan jalur hijau yakni Perbup Nomor 27 Tahun 2011 tentang penetapan sawah berkelanjutan sebagai sawah abadi. Adanya peraturan tersebut telah menunjukan besarnya komitmen dari pemerintah dan masyarakat untuk mempertahankan sawah di Desa Jatluiwih dan menunjukan daerah 
mana saja yang dilarang untuk membangun yakni salah satunya kawasan warisan budaya dunia Subak Jatiluwih. Selain itu, dengan adanya aktivitas pariwisata yang semakin pesat ini membuat Pemerintah Kabupaten Tabanan bersama-sama seluruh komponen masyarakat desa untuk bersinergi dalam pengelolaan pariwisata di Desa Jatiluwih dengan tetap memperhatikan status Subak Jatiluwih sebagai obyek utama yang dinobatkan sebagai sebuah warisan budaya dunia oleh UNESCO. Adanya sinergitas tersebut sangat diperlukan sebagai upaya pelestarian kawasan yang sangat memperhatikan pembangunan berkelanjutan di Desa Jatiluwih.

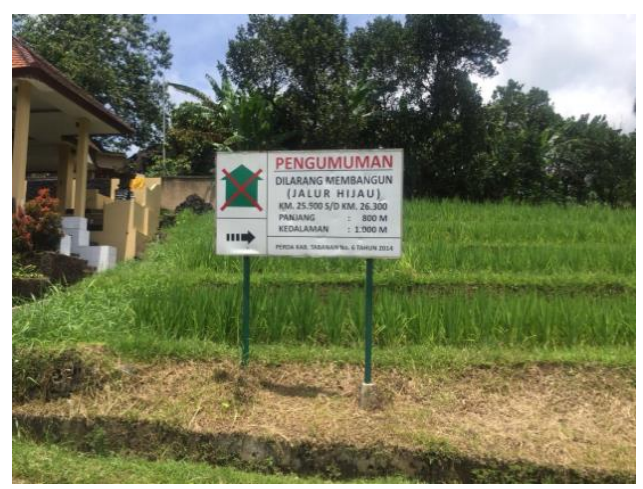

Gambar 4.2.1 Papan pengumuman larangan membangun di kawasan warisan budaya dunia Desa Jatiluwih

Proses sinergitas yang dilakukan antara seluruh pihak, khususnya pemerintah desa dinas maupun desa adat dan subak itu sendiri memiliki peranan yang sangat penting. Adapun sinergi dalam hal ini dipahami sebagai operasi gabungan atau perpaduan unsur untuk menghasilkan output yang lebih baik (Najiyati dkk, 2011). Hal tersebut dikarenakan dalam aktivitas pariwisata di Desa Jatiluwih terdiri dari berbagai tahapan yaitu perencanaan, pengawasan, dan implementasi agar terwujud kegiatan pariwisata yang memiliki tujuan untuk mencapai pembangunan berkelanjutan. Desa Jatiluwih dapat berjalan tetapi dengan tetap memperhatikan aspek lingkungan yang menjadi tujuan utama dinobatkannya Subak Jatiluwih sebagai warisan budaya dunia.Sinergitas antara Pemerintahan Desa dengan Kelembagaan Lokal Subak dalam mewujudkan pembangunan berkelanjutan di Desa Jatiluiwih dengan status sebagai warisan budaya dunia dalam penelitian ini akan dianalisis menggunakan teori Sinergitas menurut Najiyati dkk (2011) sebagai berikut :

\section{Komuikasi}

Dalam menghasilkan suatu sinergi yang baik antara Pemerintahan Desa Jatiluwih dengan Kelembagaan Lokal Subakdapat dilihat dari bagaimana komunikasi yang terjalin diantara kedua pihak itu terwujud. Komunikasi yang dimaksud disini menurut Arifin (2000) merupakan proses yang secara umum digunakan manusia dalam melakukan interaksi sosialnya. Adapun komunikasi yang dilakukan disini dianggap sangat penting karena di Desa Jatiluwih terdapat 3 lembaga yang mengatur dan masingmasing memiliki kedudukan sama dimana keberadaan ketiga lembaga 
inilah yang menjadi keunikan Bali sehingga ketiga lembaga tersebut yaitu pemerintah desa adat, pemerintah desa dinas dan kelembagaan lokal subak yang harus saling bersinergi.

Adapun sinergi yang dimaksud adalah dengan selalu melakukan komunikasi internal dalam hal perencanaan suatu kegiatan yang mendukung pengembangan pariwisata di Jatiluwih, dimana komunikasi itu dianggap penting karena ketiga lembaga tersebut merupakan suatu jejaring yang harus berkomunikasi antara satu dengan yang lain. Adapun bentuk komunikasi yang dilakukan adalah dengan mengadakan suatu rapat bersama dengan seruluh pihak termasuk dinas terkait melalui beberapa tahapan-tahapan sebelumnya yang perlu dilakukan agar rapat yang dilaksanakan dapat berjalan dengan efektif.

Sedangkan untuk komunikasi eksternal, baik pemerintah desa maupun anggota subak secara rutin melakukan komunikasi langsung dilapangan untuk memberikan sosialisasi dan pelatihan-pelatihan. Adapun sosialisasi dan pelatihan tersebut biasanya turut mengundang pihak dari Dinas Pariwisata kabupaten Tabanan yang dalam hal ini berperan sebagai Leading Sector untuk memberikan pembinaan pembinaan mengenai masalah kebersihan, kesehatan yang dapat berdampakterhadap pembangunan pariwisata berkelanjutan di Desa Jatiluwih.

Terkait komunikasi eksternal hingga saat ini tidak terlalu mengalami kendala, namun masih terdapat permasalahan yang dilihat terkait komunikasi yang terjalin antara pihak pemerintah desa dinas dengan lembaga subak. Hal ini berkenaan dengan keberadaan investor asing yang menanamkan modalnya untuk membangun fasilitas penunjang pariwisata seperti restoran dan villa. Hal ini sesuai dengan hasil wawancara yang dilakukan dengan I Wayan Mustra, SH selaku ketua subak yang menyatakan bahwa :

"kalau investor asing itu memang masing ada beberapa investor asing, selama kita masih bisa bekerjasama untuk melestraikan sawah, banayk ini sawah-sawa milik investor asing, tapi merka juga ingin melestraikan sawah kita terima, merek juga iku terikat awigawig." (Wawancara 15 Agustus 2019)

Namun, hal tersebut berbading terbalik dengan hasil wawancara yang dilakukan dengan Bapak I Nengah Kartika, S.Sos selaku Kepala Desa Jatiluwih yang menyatakan bahwa :

"kalau dulu zaman sebelum saya itu banyak, kalau sekarang sudah di status quo kan, baru kita itu duduk di desa itu kita ganggu kan tidak manusiawi, jadi itu kita diamkan tidak boleh melakukan 
pengembangan lagi, karena kita sudah komit non hotel dan villa, yang kitaperbolehkan itu home stay." (Wawancara 15 Agustus 2019)

\section{Perbedaan informasi yang} didapat memperlihatkan bahwa terdapat sedikit permasalahan terkait transparansi mengenai kebijakan yang diberikan kepada investor yang ingin menanamkan modalnya di Desa Jatiluwih. Sedangkan, untuk pemerintah adat sendiri yang selaku pihak pengawas tidak terlalu memberikan pernyataan apapun mengenai kedatangan investor karena sampai saat ini pihak adat belum membuat awig-awig (hukum adat) yang mengatur tentang kedatangan investor asing padahal kedatangan investor yang tidak terkontrol dapat menjadi ancaman terhadap para pelaku usaha lokal maupun keberadaan sawah abadi di Desa Jatiluwih karena berakibat pada maraknya

pembangunan.

Transparansi mengenai kedatangan investor sangat diperlukan karena apabila tidak diatur sedemikian rupa maka hal tersebut akan menjadi sebuah ancaman.

\section{Koordinasi}

Dalam menjalankan suatu kegiatan tidak akan bisa dilakukan hanya dengan berkomunikasi yang tepat dan sesuai dengan apa yang dikerjakan. Dalam proses pencapaian pembangunan berkelanjutan di Desa Jatiluwih sebagai daerah pariwisata , karena menyangkut kesejahteraan bersama dalam mencapai tujuan, diperlukan komunikasi dan koordinasi yang bagus anatara pemerintah Desa Jatiluwih dengan Kelembagaan Lokal Subak itu sendiri sehingga proses kerjasama dalam mewujudkan pembangunan berkelanjutan itu sangat diperlukan agar berjalan dengan baik dan sesuai dengan tujuan yang telah ditetapkan. Terdapat 4 sub indikator yang akan dianalisis untuk dapat mewujudkan koordinasi yang efektif, anatara lain :

\section{a. Hubungan Langsung}

Hubungan langsung merupakan koordinasi yang dicapai melalui hubungan pribadi langsung. Dimana dalam mewujudkan pembangunan berkelanjutan berbasis subak sebagai warisan budaya dunia di Desa Jatiluwih pemerintah desa dengan lembaga subak telah melakukan koordinasi langsung melalui pertemuan secara rutin yang berkenaan tentang perencanaan sampai dengan proses evaluasi terkait dengan kendalakendala yang dialami dalam mewujudkan pembangunan berkelanjutan.

Terkait koordinasi yang dilakukan melalui hubungan langsung, antara pemerintah desa dengan lembaga subak telah berjalan optimal. Selain itu pemerintah daerah juga ikut bersinergi untuk melakukan hubungan langsung dengan masyarakat dengan memberikan sosialisasi, pembinaan dan 
pelatihan yang dapat menunjang kegiatan pariwisata tetapi dengan masih memperhatikan subak sebagai warisan budaya dunia untuk mencapai pembangunan berkelanjutan.

\section{b. Kontinuitas}

Koordinasi adalah suatu proses yang continue dan harus berlangsung pada semua waktu mulai dari tahap perencanaan. Dimana dalam hal ini koordinasi yang dilakukan antara pemerintah desa dengan lembaga subak dalam mewujudkan pembangunan berkelanjutan yang berpedoman pada subak sebagai warisan budaya dunia telah dilakukan secara berkelanjutan melalui rapat rutin dengan rentang waktu tertentu yang bertujuan untuk membahas perencanaan dan juga setiap tahun melakukan pemantauan dan pembinaan terhadap anggota subak seperti yang telah disebutkan sebelumnya.

\section{c. Tujuan Yang Jelas}

Dalam berkoordinasi harus memiliki tujuan yang jelas sehingga koordinasi yang dilakukan akan berjalan efektif. Terkait koordinasi yang dilakukan antara pemerintah desa dengan lembaga subak dalam bersinergi untuk mewujudkan pembangunan berkelanjutan yaitu harus sesuai dengan tujuan yang ingin dicapai dengan berkoordinasi dalam hal perencanaan penataan daerah yang dapat dibangun dan tidak dapat dibangun, bantuan dana untuk kebutuhan petani, serta halhal lainnya yang dapat menunjang pembangunan pariwisata berkelanjutan yang ingin dicapai.

Dalam hal ini nasib petani sebagai anggota subak sangat perlu diperhatikan karena petani merupakan obyek utama dalam pariwisata yang ada di Desa Jatiluwih. Terlebih kendala yang dialami terkait dengan masalah irigasi yang cukup penting bagi keberadaan Subak Jatiluwih. Hal tersebut sesuai dengan hasil wawancara bersama dengan Bapak I Wayan Mustra selaku Ketua Subak Desa Jatiluwih yang menyatakan bahwa :

"satu di irigasi aja sebernarnya, memang ada irigasi yang merupakan peninggalan orde baru yang sudah sekian tahun belum ada perbaikan. Memang sih kita dari pekaseh sudah mengajukan proposal tapi masih belum memang sih di janjikan tahun 2012." (Wawancara 15 Agustus 2019)

Irigasi merupakan hal yang paling vital didalam keberlangsungan kegiatan para anggota subak dalam mengelola sawahnya, namun dari keempat lembaga yang ada di Desa Jatiluwih, subaklah yang mendapat maanfaat paling sedikit dari kegiatan pariwisata yang ada. Adapun pembagian pendapatan dari Desa Jatiluwih adalah sebanyak 45 
persen diberikan kepada

Pemerintah Daerah, 55 persen bagian untuk Desa Jatiluwih itu kemudian dibagi lagi yaitu Desa Adat Jatiluwih (30 persen), Desa Adat Gunungsari (20 persen), Desa Dinas Jatiluwih (25 persen), dan Subak (25 persen).

Terakhir, dari 25 persen untuk subak dibagi lagi untuk subak sawah sebanyak tujuh kelompok dan satu subak basah (sawah) dan subak kering (ladang). Artinya, tiap subak sawah masing-masing mendapat 3 persen sedangkan subak kering sebanyak 4 persen. Dan pembagian tersebut hanya diberikan untuk pengurus subak, bukan langsung ke petani. Secara langsung hal ini menandakan bahwa subak merupakan lembaga yang mendapat tetesan paling kecil. Padahal, merekalah ujung tombak dari pelestarian subak di Jatiluwih dan sebagai pelaku utama kegiatan pariwisata subak Jatiluwih yang seharusnya diberikan bantuan dana yang lebih banyak agar dapat melakukan tugasnya secara optimal. Hal tersebut dikarenakan sampai saat ini yang paling dominan dalam pengelolaan pariwisata di Desa Jatiluwih adalah pemerintah desa dinas itu sendiri dengan membentuk sebuah badan yang disebut dengan Badan Pengelola Daerah Tujuan Wisata Desa Jatiluwih. Terlebih yang menjadi kendala disini adalah sistem irigasi yang menjadi modal utama sehingga untuk melakukan proses perbaikan terhadap saluran irigas yang rusak seharusnya tidak menunggu bantuan terlalu lama dari instansi yang menaungi karena bagaimanapun petanilah yang paling mengetahui apa yang mereka butuhkan.

Dalam hal ini terdapat pernyataan yang berbanding terbalik antara apa yang disampaikan oleh Bapak I Nengah Kartika selaku Kepala Desa dengan apa yang disampaikan oleh Ketua Subak, yakni beliau menyampaikan bahwa saat ini petani di Desa Jatiluwih sudah cukup sejahtera dengan adanya pembagian pendapatan tersebut karena petani sudah tidak perlu lagi mengeluarkan dana pribadi untuk kegiatan upacara di Subak tetapi beliau melupakan bahwa hal yang menjadi prioritas disini adalah sistem irigasi yang menjadi modal utama subak untuk melakukan upaya pelestarian masih perlu dilakukan perbaikan.

Maka, dalam hal pencapaian tujuan melalui koordinasi pemerintah desa dengan lembaga subak terkait dengan pemberian hasil pendapatan untuk perbaikan fasilitas dan infrastruktur dilapangan masih terdapat permasalahan yakni mengenai bantuan dana untuk perbaikan sistem irigasi yang ditunggu anggota subak sejak tahun 2012 sampai sekarang masih belum terealisasikan. Sehingga terlihat 
bahwa koordinasi dilapangan belum maksimal.

Selain itu, permasalahan lain juga muncul mengenai apa makna dan tujuan daripada pemberian predikat warisan budaya dunia kepada Subak Jatiluwih disamping penetapan Desa Jatiluwih sebagai Daerah Tujuan Wisata (DTW) maupun desa wisata. Karena ketika ditetapkan sebagai warisan budaya dunia, Jatiluwih hanya dianggap sebagai daerah tujuan pariwisata, bukan lagi suatu kawasan lahan pertanian yang harus dilestarikan untuk keperluan generasi di masa depan. Kebingungan ini juga disampaikan oleh Kepala Desa Jatiluwih yakni Bapak I Nengah Kartika, S.Sos yang menyatakan bahwa :

"Untuk harapan sih agar predikat warisan budaya dunia ini tetepmelekat di DTW Jatiluwih, dan juga disatu sisi bagaimana pemerintah provinsi dan pemerintah pusat utamanya bisa betul-betul peduli, biar artinya terjawab pertanyaan masyarakat tentang apa yang bisa saya dapat dari warisan budaya dunia, kan banyak yang bertanya seperti itu, tiang jawab begini jangan berfikir seperti itu tapi apa yang yangbisa kita perbuat dengan adanyawarisan budaya dunia yang didalamnya ada DTW yang kita kelola, jadi itujawaban sementara dari saya." (Wawancara 15 Agustus 2019)

Adanya kebingungan yang dialami oleh masyarakat desa seharusnya diperjelas oleh pihakpihak yang ikut terlibat dalam pengajuan Subak Jatiluwih sebagai warisan budaya dunia. Karena pada kenyatannya, hingga saat ini badan pengelola WBD di tingkat provinsi itu belum terbentuk. Pemkab Tabanan kemudian justru membentuk Badan Pengelola Daya Tarik Wisata (DTW) Jatiluwih setahun setelah mendapat pengakuan karena adanya teguran dari UNESCO melalui pemerintah pusat dimana pembentukan badan pengelola DTW tersebut berbeda tujuan dan fungsinya. Tidak seperti yang direncanakan bersama oleh tim penyusun proposal ke UNESCO. Badan Pengelola WBD seharusnya berorientasi pada upaya konservasi dan preservasi. Sedangkan Badan Pengelola DTW adalah untuk kepentingan industri pariwisata yang cenderung mengeksploitasi.

\section{d. Komunikasi Yang Efektif}

Komunikasi yang efektif menjadi salah satu persyaratan koordinasi yang baik. Dimana dalam mewujudkan pembangunan berkelanjutan berbasis subak sebagai warisan budaya dunia pada tahap perencanaan sampai pemantauan pihak pemerintahaan desa dan lembaga subak telah melakukan komunikasi yang efektif 
guna tercapainya suatu tujuan, yaitu dengan melakukan pertemuan langsung dalam suatu rapat membahas terkait kegiatan yang menunjang pengembangan desa wisata serta penyampaian permasalahan atau kendala yang dialami, melalui via telepon ataupun melakukan sosialisasi dan pemantauan langsung.

\section{Penutup}

Sinergitas Pemerintah Desa dan Kelembagaan Lokal Subak dalam Mewujudkan Pembangunan Berkelanjutan di Pedesaan berbasis Subak Sebagai Warisan Budaya Dunia (Studi Kasus : Subak Jatiluwih, Kabupaten Tabanan) yang ditinjau melalui indikator komunikasi dan koordinasi dari konsep sinergitas adalah sebagai berikut:

1. Pada indikator komunikasi terkait komunikasi internal dan eksternal yang terjalin dalam proses kegiatan perencanaan dan pembinaan sudah berjalan optimal. Namun masih terdapat permasalahan dilapangan terkait komunikasi yang terjalin antara Pemerintahan Desa Jatiluwih dengan lembaga.

2. Pada tahap koordinasi antara pemerintahan desa dengan lembaga subak dalam mencapai tujuan pembangunan berkelanjutan berbasis subak sebagai warisan budaya dunia masih belum maksimal, hal ini dikarenakan dalam pemberian bantuan fasilitas dan dana masih belum terealisasi sepenuhnya.

Adapun rekomendasi yang dapat penulis sampaikan, yaitu :

1. Direkomendasikan kepada Pemerintahan Desa Jatiluwih dan Kelembagaan Lokal Subak Jatiluwih, agar dapat lebih meningkatkan kembali proses komunikasi dan koordinasi yang dilakukan. Sehingga nantinya tidak terjadi misskomunikasi dilapangan yang dapat menghambat perkembangan pariwisata yang belandaskan pembangunan berkelanjutan.

2. Direkomendasikan bagi Pemerintah Daerah untuk segera membentuk Badan Pengelola Warisan Budaya Dunia untuk menjawab pertanyaan dari masyarakat mengenai makna dan tujuan pemberian predikat tersebut serta untuk mengontrol kegiatan pariwisata agar tidak terlalu mengeksploitasi kawasan yang seharusnya menjadi kawasan pelestarian.

3. Direkomendasikan untuk masyarakat Jatiluwih agar ikut mengkontrol dan sadar akan segala kegiatan pariwisata yang ada agar tidak terjadi alih fungsi lahan yang berlebihan yang dapat mengancam status Subak Jatiluwih sebagai warisan budaya dunia untuk 
kepentingan pembangunan berkelanjutan dimasa depan.

\section{Daftar Pustaka}

Antara, Made. 2017. Ekowisata Subak Jatiluwih,Tabanan , Bali. Denpasar : Palawa Sari.

Ardee. .Subak, Filosofi Keserasian dalam Masyarakat Agraris Pulau Dewata. Tersedia pada

https://www.indonesiakaya.c om/jelajah-

indonesia/detail/subak-

filosofi-keserasian-dalammasyarakat-agraris-pulaudewata. Diakses pada tanggal 21 Juli 2019.

Bali Glory. Subak: Sistem Pengairan Sawah (irigasi) Tradisional Bali. Tersedia pada :http://www.id.baliglory.co m/2016/04/subakbali.html. Diakses pada tanggal 8 Agustus 2019.

Binford, L. 1968. Post-Pleistocene Adaptations. Dalam New Perspektive in Archaelogy ed. L.R. Binford dan S.R Binford. Chicago: Aldine. Halaman 313.

Diyah Sri Widari, Dewa Ayu. 2015. Jurnal: Perkembangan Desa Wisata Jatiluwih Setelah UNESCO Menetapkan Subaknya Sebagai Bagian Dari Warisan Budaya Dunia. Tersedia pada: https://ojs.unud.ac.id/index.p hp/jumpa/article/download/1 5209/10069/v . Diakses pada tanggal 11 Agustus 2019.

Irham, Nizar. 2018.

Pengertian Subak Dan

Pendapat Para Ahli. Tersedia pada

:https://id.scribd.com/doc/129

508356/Pengertian-Subak-

Dan-Pendapat-Para-Ahli.

Diakses pada tanggal : 8

Agustus 2019

Irham, Nizar. 2018. Pengertian Subak Dan Pendapat Para Ahli. Tersedia pada :https://id.scribd.com/doc/129 508356/Pengertian-SubakDan-Pendapat-Para-Ahli. Diakses pada tanggal : 8 Agustus 2019

Muhajir, Anton.2019. Nasib Jatiluwih setelah Menjadi Warisan Budaya Dunia (3).Tersedia pada :https://www.mongabay.co.id /2019/04/29/nasib-jatiluwihsetelah-menjadi-warisanbudaya-dunia-3/ . Dikases pada tanggal 20 Agustus 2019

Najiyati, Sri dan Susilo, Rahmat Topo . 2011. Sinergitas Pemerintah dalam Pembangunan Kota Terpadu Mandiri. Jurnal ketransmigrasian Vol. 28 No. 2011. 133-124.(Jakarta,Pusat Litbang Ketransmigrasian)

Pandu, Akbar. 2017. Jurnal: Sinergitas Aktor Kepentingan Dalam Penyelenggaraan Pemerintah Desa. Tersedia pada:

http://jurnal.unmer.ac.id/inde 
x.php/jkpp/article/download/

1421/907. Diakses pada tanggal 10 Agustus 2019

Pemerintah Kabupaten Buleleng. 2017. Pembangunan Ekonomi Dan Konsep Pembangunan

Berkelanjutan. Tersedia pada

https://bulelengkab.go.id/de tail/artikel/pembangunanekonomi-dalam-konseppembangunanberkelanjutan-68. Diakses pada 17 Juli 2019

Peraturan Daerah Bali No. 9 tahun 2012

Peraturan Daerah Provinsi Bali Nomor 4 Tahun 2019

Perbup Nomor 27 Tahun 2011

Perda Nomor 6 Tahun 2014 Tentang Kawasan Jalur Hijau

Prasetijo, Adi. 2009. Jurnal :Good Governance dan Pembangunan

Berkelanjutan. Tersedia pada

:https://etnobudaya.net/2009 /10/20/good-governancedan-pembangunanberkelanjutan/. Diakses pada tanggal 20 Agustus 2019

Radar Planologi.2017.Pengertian Pembangunan

Berkelanjutan Menurut Para Ahli. Tersedia pada: http://www.radarplanologi. com/2015/11/pengertianpembangunanberkelanjutan.html. Diakses pada 15 Juli 2019
Radar Planologi.2017. PrinsipPrinsip Pembangunan Berkelajutan. Tersedia pada http://www.radarplanologi. com/2015/11/prinsipprinsip-pembangunanberkelanjutan.html. Diakses pada 14 Juli 2019

Sistha, Aruma. 2018. Subak, Sistem Pertanian yang Menjaga Keseimbangan. Tersedia pada

:https://www.genagraris.id/s ee/subak-sistem-pertanianyang-menjagakeseimbangan . Diakses pada tanggal : 8 Agustus 2019.

Undang-Undang No. 5 Tahun 1979

Undang-Undang No. 6 Tahun 2014 
